\title{
PENGALIHAN JABATAN STRUKTURAL KE JABATAN FUNGSIONAL : SUATU ANALISA KOMPENSASI ATAS PENGHAPUSAN JABATAN ESELON III DAN IV DI PUSAT PENGEMBANGAN SUMBER DAYA MANUSIA APARATUR
}

\author{
Fahmi Aulia Rakhman \\ Pusat Pengembangan Sumber Daya Manusia Aparatur \\ Email : fahmi.rakhman@esdm.go.id
}

\begin{abstract}
ABSTRAK
Penelitian ini menganalisa rencana pengalihan jabatan struktural ke jabatan fungsional. Fokus penelitian ini adalah mengenai kompensasi atau penghasilan dari pegawai dalam jabatan struktural III dan IV yang akan berpindah menjadi jabatan fungisonal tertentu yang setara. Metode yang digunakan adalah pendekatan yuridis normatif. Ruang lingkup dari penelitian ini dibatasi hanya di Pusat Pengembangan Sumber Daya Manusia Aparatur (PPSDMA). Hasil penelitian menunjukkan bahwa penghasilan yang diterima pegawai struktural eselon III lebih besar daripada pegawai dalam jabatan fungisonal tertentu setara yang relevan di PPSDMA, sementara untuk jabatan struktural eselon IV akan mengalami peningkatan penghasilan jika beralih ke jabatan jabatan fungsional tertentu setara yang relevan di PPSDMA. Kemudian disimpulkan juga bahwa beberapa jabatan fungsional tertentu besaran tunjangannya belum sesuai dengan peritungan bobot jabatan.
\end{abstract}

Kata kunci : jabatan struktural, jabatan fungsional, pengalihan jabatan, tunjangan

\section{Abstract}

This research analyze the reposition of employee orientation from struktural to functional position. This research focus on compensation or income received by civil servants who are redirected from functional from struktural position. The method used is a normative juridical approach.The scope of research was limited only within Human Resource Development Center for Government Apparatus. The results showed that the income received by Echelon III bigger than the employees have the same job class as expert level functional job, meanwhile the income received by echelon IV will increase if they are reposition from struktural to functional position. It is also concluded that the amount of some specific functional job allowance has not been based on the calculation of job weight.

Keywords: struktural positions, functional positions, job reposition, allowances

\section{PENDAHULUAN}

Revolusi Industri 4.0 menjadi pelajaran bagi organisasi pemerintah bertransformasi diri menjadi bentuk ideal agar dapat menghadapi ancaman dan memanfaatkan peluang yang ada. Transformasi organisasi pemerintah merupakan salah satu alternatif yang dapat ditempuh dalam rangka mewujudkan organisasi yang berorientasi layanan publik. Transformasi organisasi pemerintah perlu terus diarahkan ke dalam perubahan dari desain lama yang kurang kondusif ke desain baru yang lebih kondusif untuk terus mengembangkan inovasi, manajemen inovasi dan mengelola risiko serta integrasi organisasi dalam membangun kolaborasi dan sinergitas. Inovasi tingkat organisasi menjadikan pertumbuhan dan berkembangnya kreativitas yang tidak terkungkung oleh hirarki yang ketat, hal ini memerlukan adanya perubahan struktur organisasi, proses komunikasi dan koordinasi dan menghilangkan hambatan-hambatan struktural. Struktur organisasi pemerintah yang selama ini mekanistis, hierarkis birokratis, departementalisasi yang kaku, formalisasi tinggi dan dan sentralistis perlu terus ditransformasi ke arah organisasi yang organik, yang ditandai dengan informasi yang mengalir bebas, formalisasi rendah dan tim lintas fungsi, guna menjawab ketidakpastian yang tinggi dan lingkungan strategis organisasi pemerintah yang semakin dinamis dan kompleksitas yang tinggi. ${ }^{1}$

Pusat Pengembangan Sumber Daya Manusia Aparatur (PPSDMA) menghadapi 2 (dua) masalah

\footnotetext{
${ }^{1}$ https://setkab.go.id/revolusi-industri-4-0-dan-transformasi-organisasi-pemerintah/
} 
utama Sumber Daya Manusia Aparatur, yaitu kualitas dan distribusi (penempatan). Kualitas Sumber Daya Aparatur masih merupakan permasalahan serius jika dikaitkan dengan kinerja. Reorganisasi dapat berpengaruh terhadap struktur, yaitu semakin besar atau semakin ramping. Organisasi pemerintah secara umum dibentuk dengan struktur yang besar sehingga dipandang tidak efisien dan tidak ekonomis. Dimensi lain dari implikasi reorganisasi yang perlu mendapat perhatian dengan cermat adalah tatalaksana (manajemen) organisasi. PPSDMA masih mempunyai permasalahan mendasar dalam pelaksanaan fungsifungsi manajemen. Simplifikasi dan sinkronisasi kegiatan masih sering mengalami kendala dengan kuatnya kepentingan antar unit atau bidang.

Tiada kehidupan tanpa perubahan. Setiap kehidupan dalam masyarakat sedikit maupun banyak, besar ataupun kecil pasti mengalami berbagai perubahan. Organisasi sebagai salah satu bentuk kehidupan dalam masyarakat pasti mengalami perubahan. Organisasi menghadapi tantangan baik yang berasal dari dalam diri organisasi maupun berasal dari lingkungan yang merupakan penyebab organisasi harus dirubah.

Dalam pidato pelantikannya, Presiden Joko Widodo mengungkapkan rencananya untuk memangkas jumlah eselon yang tadinya 5 (lima) menjadi 2 (dua). Terkait dengan rencana tersebut, menurut Kepala Biro Humas Badan Kepegawaian Negara (BKN) Mohammad Ridwan hingga saat ini ada sekitar 430.000 Aparatur Sipil Negara (ASN) yang berada di level eselon III, IV dan V. Untuk jumlah eselon I di Indonesia ada 575 orang atau 0,12 persen, sedangkan eselon II ada 19.463 orang atau 4,23 persen, sehingga total eselon I dan II di Indonesia ada sekitar 20.000 atau 4,35 persen. Total jumlah eselon I sampai dengan $\mathrm{V}$ adalah 460.067 orang. $^{2}$ Penghapusan ini salah satunya bertujuan untuk memindahkan orientasi dari jabatan struktural ke jabatan fungsional. Penghapusan diharapkan mampu menguangi biaya yang tidak diperlukan seperti untuk pemberian fasilitas dinas dan jabatan kepada pejabat eselon III dan IV. Penghapusan jabatan eleson III dan IV bertujuan mengubah pola pikir ASN yang selama ini cenderung mengejar jabatan tanpa melaksanakan tugasnya secara maksimal. Perampingan ini juga dilakukan guna menjaring ASN yang berkualitas yang mampu melayani publik secara baik.

Berdasarkan hal-hal tersebut, maka penulis tertarik untuk menganalisa keterkaitan penghapusan jabatan eselon III dan IV dengan kom- pensasi atau penghasilan yang diterima ASN yang berpindah dari jabatan struktural ke jabatan fungsional dengan ruang lingkup di Pusat Pengembangan Sumber Daya Manusia Aparatur (PPSDMA).

Hasil penelitian Hendrik Budhi Prasetyo (2009), tentang perubahan organisasi pada Pusdik Brimob yang dilakukan berdasarkan Keputusan Kapolri Nomor Pol Kep/53/X/2002 menunjukan bahwa Kep 53/X/2002 mengamanatkan penyederhanaan tingkat kompleksitas, peningkatan formalisasi, dan desentralisasi kewenangan pada organisasi. Perubahan-perubahan ini menciptakan sebuah struktur organisasi yang unik. Pada implementasinya perubahan tersebut harus berhadapan dengan budaya organisasi yang menunjukan bahwa Pusdik Brimob bukan lagi sekedar sebuah organisasi formal namun telah berkembang menjadi sebuah lingkungan sosial.

\section{TINJAUAN TEORI}

\section{Pengertian Restrukturisasi Organisasi}

Menurut Sedermayanti (2000) mengemukakan bahwa upaya restrukturisasi dalam suatu organisasi dapat dilakukan melalui upaya manajemen dengan cara melakukan penataan ulang atau rekayasa ulang (reengineering) sehingga perusahaan dapat melakukan adaptasi terhadap pengaruh perubahan lingkungannya, sehingga perusahan akan tetap bertahan hidup. Adapun tujuan dari restrukturisasi menurut Gouillart dan Kelly (1995) adalah "Menyiapkan perusahan/ organisasi untuk dapat mencapai tingkat kompetisi yang digunakan, hal ini berhubungan dengan organisasi yang ramping dan fit". Restrukturisasi adalah dimensi yang sangat diperlukan bagi kelangsungan hidup suatu organisasi. Restrukturisasi merupakan bagian yang penting, tanpanya organisasi akan kehilangan kemampuan untuk bertahan. Dengan restrukturisasi organisasi dapat menata ulang strukturnya sesuai dengan visi dan misi. (Gouillart dan Kelly, 1995).

Menurut Ingraham \& Romzek (1994) dalam Sadu Wasistiono (2002): Penataan ulang (reinventing) diartikan sebagai "fundamental redesign of the system of government, the civil service system". Agenda utamanya meliputi :

a. Memperkecil ukuran organisasi pemerintah;

b. Privatisasi;

c. Memperbaharui manajemen dalam semua aspek.

Sekarang ini hampir dalam setiap aspek kehidupan manusia tidak bisa terlepas dari peran

\footnotetext{
${ }^{2}$ https://tirto.id/bkn-ada-430000-pejabat-eselon-iii-iv-v-di-seluruh-indonesia-ekcr
} 
organisasi. Oleh karena itu tidak berlebihan jika dikatakan bahwa manusia disebut sebagai "manusia organisasi" (homo organismus). Sedangkan di lain pihak tuntutan, keinginan dan kebutuhan manusia semaking besar dan beragam. Tuntutan kebutuhan yang semakin besar dan beragam dari waktu ke waktu inilah yang mengharuskan manusia mengubah organisasi sebagai wadah aktivitasnya.

Dari berbagai pendapat di atas, bila dikaitkan dengan perampingan maka perampingan birokrasi merupakan perubahan yang terjadi pada struktur birokrasi yang kompleks menjadi sederhana. Ini berarti penyederhanaan pola wewenang, saluran dan jaringan informasi, jenjang hirarki, rentang kendali, hubungan kerja, prosedur dan tata kerja. Dengan demikian perampingan struktur organisasi birokrasi dapat mempermudah dan mempercepat pemberian laporan, perintah, wewenang dan tanggung jawab, sehingga pekerjaan dapat selesai dengan efektif dan efisiensi dan pada akhirnya dapat mempengaruhi hasil kerja.

\section{Pengertian Kompensasi}

Menurut Hasibuan (2010: 118), kompensasi adalah semua pendapatan yang berbentuk uang, barang langsung atau tidak langsung yang diterima karyawan sebagai imbalan atas jasa yang diberikan kepada perusahaan.

Kompensasi menurut adalah segala sesuatu yang diterima para karyawan sebagai balas jasa untuk kerja mereka (Handoko, 2012: 155).

Menurut Andrew E. Sikula dalam Mangkunegara (2009:83) mengemukakan bahwa proses administrasi upah atau gaji (kadang-kadang disebut kompensasi) melibatkan pertimbangan atau keseimbangan perhitungan. Kompensasi meliputi bentuk pembayaran tunai langsung, pembayaran tidak langsung dalam bentuk manfaat karyawan, dan insentif untuk memotivasi karyawan agar bekerja keras untuk mencapai produktivitas yang tinggi (Mangkuprawira, 2011:203). Kompensasi merupakan suatu bentuk biaya yang harus dikeluarkan oleh perusahaan dengan harapan bahwa perusahaan akan memperoleh imbalan imbalan dalam bentuk prestasi kerja dari karyawan (Sofyandi, 2008:157). Kompensasi adalah segala sesuatu yang diterima oleh karyawan sebagai balas jasa untuk kerja atau pengabdian mereka (Soekidjo 2009: 142). Kompensasi merupakan sesuatu yang diterima karyawan sebagai pengganti kontribusi jasa mereka pada perusahaan (Veithzal Rivai, 2009:741).

\section{Komponen Kompensasi}

Komponen Kompensasi (Veithzal Rivai, 2009:744), yaitu :

a. Gaji adalah balas jasa dalam bentuk uang yang diterima karyawan sebagai konsekuensi dari kedudukannya sebagai seorang karyawan sebagai seorang karyawan yang memberikan sumbangan tenaga dan fikiran dalam mencapai tujuan perusahaan.

b. Upah merupakan imbalan finansial langsung yang dibayarkan kepada karyawan berdasarkan jam kerja, jumlah barang yang dihasilkan atau banyaknya pelayanan yang diberikan. Jadi tidak seperti gaji yang jumlahnya relative tetap, besarnya upah dapat berubah-ubah tergantung pada keluaran yang dihasilkan.

c. Insentif merupakan imbalan langsung yang dibayarkan kepada karyawan karena kinerjanya melebihi yang standar yang ditentukan. Insentif merupakan bentuk lain dari upah langsung diluar upah dan gaji yang merupakan kompensasi tetap, yang biasa disebut kompensasi berdasarkan kinerja.

\section{Tujuan Pemberian Kompensasi}

Tujuan dari pemberian kompensasi yaitu :

a. Mendapatkan karyawan yang berkualitas

Organisasi saling bersaing dipasar tenaga kerja untuk mendapatkan karyawan yang berkualitas dan memenuhi standar yang diminta organisasi.

b. Mempertahankan karyawan yang sudah ada Dengan adanya kompensasi yang kompetitif, organisasi dapat mempertahankan karyawan yang potensial dan berkualitas untuk tetap bekerja.

c. Adanya keadilan

Adanya administrasi kompensasi menjamin terpenuhnya rasa keadilan pada hubungan antara manajemen dan karyawan.

d. Perubahan sikap dan perilaku

Adanya kompensasi yang layak dan adil bagi karyawan hendaknya dapat memperbaiki sikap dan perilaku yang tidak menguntungkan serta mempengaruhi produktivitas kerja.

e. Efisiensi biaya

Program kompensasi yang rasional membantu organisasi untuk mendapatkan dan mempertahankan sumber daya manusia pada tingkat biaya yang layak.

f. Administrasi legalitas

Dalam administrasi kompensasi juga terdapat batasan legalitas karena diatur dalam sebuah undang-undang. 


\section{Kategori Kompensasi}

Menurut Gugup Kismono (2011:178), kompensasi dapat dibedakan dalam dua kategori, yaitu:

\section{a. Kompensasi Finansial}

Kompensasi finansial terbagi menjadi dua bagian, yaitu :

1) Kompensasi langsung berupa pembayaran upah (pembayaran atas dasar jam kerja), gaji (pembayaran secara tetap/bulanan), dan insentif atau bonus. Pemberian gaji tetap setiap bulannya umumnya didasarkan pada nilai pekerjaan yang diembannya. Semakin tinggi nilai pekerjaan atau jabatannya akan semakin tinggi pula gaji yang diterimanya tanpa mempertimbangkan kinerja yang dihasilkannya. Penentuan nilai sebuah pekerjaan dilakukan melalui evaluasi pekerjaan. Sebaliknya, besar kecilnya gaji insentif atau bonus dikaitkan dengan kinerja seseorang atau kinerja organisasi. Jika seseorang menunjukkan kinerja yang lebih tinggi dibandingkan rekan kerjanya, maka dia berhak mendapatkan insentif lebih besar walaupun mereka menduduki jabatan yang sama.

2) Kompensasi tidak langsung berupa pemberian pelayanan dan fasilitas kepada karyawan seperti program beasiswa pendidikan, perumahan, program rekreasi, libur dan cuti, konseling finansial, dan lain-lain

\section{b. Kompensasi Non Finansial}

Kompensasi non finansial terbagi menjadi dua bagian, yaitu :

1) Kepuasan dari pekerjaan itu sendiri berupa tugas-tugas yang menarik, tantangan, tanggung jawab, pengakuan, dan rasa pencapaian

2) Kepuasan yang diperoleh dari lingkungan kerja karyawan berupa kebijakan yang sehat, supervisi yang kompeten, kerabat kerja yang menyenangkan, dan lingkungan kerja yang nyaman.

\section{Keadilan dalam Pemberian Kompensasi}

Keadilan merupakan jantungnya sistem kompensasi. Untuk mewujudkan keadilan ini maka program kompensasi harus didisain dengan mempertimbangkan baik kontribusi karyawan maupun kebutuhan karyawan. Hal ini bukan berarti bahwa kompensasi yang diberikan oleh suatu perusahaan harus berjumlah banyak (secara nominal). Perusahaan yang memberikan kompensasi secara berlebihan kepada karyawan akan dapat mencelakai diri perusahaan maupun karyawannya. Kompensasi yang berlebihan tersebut akan mengakibatkan menurunnya daya saing perusahaan, kecemburuan antar karyawan maupun ketidaknyamanan dalam diri karyawan itu sendiri (Lawler, 1971).

Menurut Simamora (2004), keadilan yang hendak dicapai melalui program kompensasi ini dapat dibedakan menjadi 3 yaitu:

\section{a) Keadilan Individual}

Teori keadilan yang diformulasikan oleh J. Stacy Adams (1965) berusaha menerangkan proses bagaimana seorang individu terpuaskan atau tidak terpuaskan terhadap suatu kompensasi (Kanungo, 1992). Pada peristiwa dimana seorang individu tidak puas, teori keadilan memprediksikan perilaku dimana seorang individu mungkin akan mencari jalan lain untuk menurunkan ketidakpuasan yang dirasakannya. Secara implisit hal ini menunjukkan bahwa teori keadilan didasarkan pada dugaan mengenai keadilan yang diharapkan oleh seorang individu dalam banyak pertukaran yang terjadi dalam kerja.

\section{b) Keadilan Internal}

Keadilan internal merupakan suatu criteria keadilan dari kompensasi yang diterima karyawan dari pekerjaannya dikaitkan dengan nilai internal masing-masing pekerjaan. Keadilan internal juga mengidentifikasikan bahwa posisi yang lebih disukai atau karyawan dengan kualifikasi lebih tinggi dalam perusahaan haruslah diberi kompensasi yang lebih tinggi pula (Smith, 1990).

Nilai suatu pekerjaan haruslah menggambarkan: (1) nilai social budaya suatu masyarakat, (2) nilai produk dan jasa yang dibuat, (3) investasi yang dilakukan dalam pendidikan, pelatihan, dan pengalaman yang dibutuhkan oleh suatu pekerjaan, (4) posisi pekerjaan dalam hirarki organisasional.

Dalam prakteknya, organisasi biasanya memfokuskan pada isi dan kontribusi suatu pekerjaan dalam menentukan nilai pekerjaan tersebut. Isi pekerjaan (job content) berkaitan dengan pengetahuan, keterampilan, kemampuan, pengalaman, dan usaha yang dibutuhkan untuk menjalankan pekerjaan tersebut. Contoh, suatu pekerjaan yang membutuhkan tingkat pengetahuan yang lebih tinggi (misal lulusan S1 atau yang sederajat) akan memiliki nilai yang lebih tinggi dibandingkan suatu pekerjaan yang hanya membutuhkan tenaga kerja dengan ijazah diploma.

\section{c) Keadilan Eksternal}

Keadilan eksternal atau sering disebut daya saing eksternal merupakan posisi kompensasi 
yang diberikan oleh suatu organisasi terhadap seorang karyawan dibandingkan dengan kompensasi yang diberikan oleh perusahaan pesaing, tentunya untuk seorang karyawan dengan suatu pekerjaan yang bernilai sama.

Kebijakan yang memperhatikan daya saing eksternal ini mempunyai 2 pengaruh terhadap tujuan, yaitu:

1) Mendorong penetapan tingkat gaji yang mencukupi/memenuhi kebutuhan karyawan dalam rangka menghargai dan mempertahankan karyawan.

2) Mengendalikan biaya tenaga kerja sehingga harga produk yang dihasilkan oleh perusahaan dapat tetap bersaing.

Daya saing eksternal ini secara langsung berpengaruh terhadap efisiensi dan keadilan tujuan, dimana pelaksanaanya harus sesuai dengan peraturan yang berlaku. Daya saing eksternal ditetapkan berdasarkan penetapan tingkat kompensasi yang diberikan pesaing pada pekerjaan yang sejenis. Tingkat kompensasi ini ditentukan dengan mengetahui kondisi pasar tenaga kerja yang relevan dan melakukan pengamatan terhadap tingkat kompensasi yang diberikan oleh perusahaan lain, kemudian menggunakan dan mengaitkan kedua informasi tersebut dengan keputusan kebijaksanaan perusahaan untuk menghasilkan suatu program kompensasi. Program kompensasi ini akan mempengaruhi bagaimana organisasi secara efisien akan dapat mempertahankan tenaga kerja yang kompeten dan mengendalikan biaya tenaga kerja tersebut.

\section{Kompensasi untukASN}

Menurut Peraturan Pemerintah Nomor 21 Tahun 2004 tentang Penyusunan Rencana Kerja Anggaran Kementrian Negara/Lembaga, Belanja Pegawai adalah kompensasi baik dalam bentuk uang maupun barang yang diberikan kepada pegawai pemerintah, baik yang bertugas di dalam maupun di luar negeri sebagai imbalan atas pekerjaan yang telah dilaksanakan, kecuali pekerjaan yang berkaitan dengan pembentukan modal. Termasuk dalam kelompok belanja pegawai ini adalah pengeluaran-pengeluaran untuk gaji dan tunjangan-tunjangan, uang makan, lembur, honorarium dan vakasi.

Gaji dan tunjangan adalah pengeluaran untuk kompensasi yang harus dibayarkan kepada pegawai pemerintah berupa gaji pokok dan berbagai tunjangan yang diterima berkaitan dengan jenis dan sifat pekerjaan yang dilakukan baik dalam bentuk uang maupun barang.

Berdasarkan Perdirjen Perbendaharaan No
PER-37/PB/2009, Pengertian gaji pokok beserta berbagai jenis tunjangan-tunjangan yang melekat pada gaji pokok yang dibayarkan kepada pegawai pemerintah adalah sebagai berikut:

\section{a. Gaji Pokok}

Gaji pokok adalah landasan dasar dalam menghitung besarnya gaji seseorang Pegawai Negeri Sipil (PNS).Hal ini disebabkan sebagian komponen perhitungan gaji sperti tunjangan istri, tunjangan anak, dan tunjangan perbaikan penghaslan dihitung atas dasar presentase tertentu atau terkait dengan gaji pokok. Besarnya gaji pokok seorang pegawai negeri sipil tergantung atas golongan ruang penggajian yang ditetapkan untuk pangkat yang dimilikinya. Karena itu, pangkat berfungsi sebagai dasar penggajian.

Besaran gaji pokok diberikan kepada pegawai sesuai dengan besaran yang tercantum dalam surat keputusan pengangkatan, surat keputusan kenaikan pangkat, surat pemberitahuan kenaikan gaji berkala, atau surat ketetapan lainnya. Besaran gaji pokok diatur dalam Peraturan Pemerintah No. 8 Tahun 2009.

\section{b. Tunjangan-Tunjangan}

Tunjangan-tunjangan yang melekat pada gaji terdiri atas tunjangan istri/suami, tunjangan anak, tunjangan jabatan struktural/fungsional, tunjangan beras, tunjangan khusus $\mathrm{PPh}$, tunjangan irian jaya/papua, tunjangan pengabdian wilayah terpencil, tunjangan umum, dan tunjangan perbaikan penghasilan.

1) Tunjangan Istri/suami

Tunjangan istri/suami adalah tunjangan yang diberikan kepada pegawai negeri yang beristri/suami. Ketentuan-ketentuan yang berkaitan dengan tunjangan istri/suami adalah

a) Diberikan untuk 1(satu) istri/suami pegawai negeri yang sah;

b) Besarnya tunjangan istri/suami adalah $10 \%$;

c) Tunjangan istri/suami diberhentikan pada bulan berikutnya setelah terjadi perceraian atau meninggal dunia;

d) Untuk memperoleh tunjangan istri/suami harus dibuktikan dengan surat nikah/akta nikah dari Kantor Urusan Agama atau Kantor Catatan Sipil.

2) Tunjangan Anak

Tunjangan anak adalah tunjangan yang diberikan kepada pegawai negeri yang mempunyai anak (anak kandung, anak tiri, dan anak angkat) dengan ketentuan:

a) Belum melampaui batas usia 21 tahun;

b) Tidak atau belum pernah menikah; 
c) Tidak mempunyai penghasilan sendiri;

d) Nyata menjadi tanggungan pegawai negeri yang bersangkutan;

e) Diberikan maksimal untuk 2(dua) orang anak;

f) Besarnya tunjangan anak adalah 2\% dari gaji pokok.

3) Tunjangan Jabatan Struktural

Tunjangan jabatan struktural adalah tunjangan jabatan yang diberikan kepada pegawai negeri yang menduduki jabatan struktural sesuai dengan peraturan perundangan dan ditetapkan dengan surat keputusan dari pejabat yang berwenang, dengan ketentuan:

a) Besaran tunjangan jabatan struktural dibedakan menurut tngkat eselon jabatan berdasarkan Peraturan Pemerintah No. 26 Tahun 2007 tentang Tunjangan Jabatan struktural;

b) Tunjangan struktural dibayarkan pada bulan berikutnya setelah tanggal pelantikan;

c) Tunjangan jabatan struktural bagi pegawai negeri yang diangkat dan dilantik dalam jabatan struktural di luar satuan unit penggajiannya, maka yang berkewajiban pengajukan permintaan

4) Tunjangan Jabatan Fungsional

Tunjangan jabatan fungsional adalah tunjangan jabatan yang diberikan kepada pegawai negeri yang menduduki jabatan fungsional sesuai dengan peraturan perundangan dan ditetapkan dengan surat keputusan dari pejabat yang berwenang menurut peraturan perundangundangan yang berlaku, dengan ketentuan:

a) Besaran tunjangan jabatan fungsional dibedakan berdasarkan peraturan presiden;

b) Tunjangan jabatan fungsional dibayarkan pada bulan berikutnya setelah tanggal melaksanakan tugas;

c) Tunjangan jabatan funsional dibuktikan dengan surat pernyataan melaksanakan tugas;

d) Untuk kepastian pembayaran tunjangan jabatan fungsional, setiap awal tahun anggaran pejabat yang berwenang diharuskan membuat surat pernyataan masih menduduki jabatan.

5) Tunjangan Beras

Tunjangan beras adalah tunjangan beras yang diberikan kepada pegawai negeri dan anggota keluarganya dalam bentuk natura (beras) atau dalam bentuk inatura (uang) dengan besaran sesuai dengan ketentuan yang berlaku. Ketentuan-ketentuan mengenai tunjangan beras diatur sebagai berikut: a) Besaran tunjangan beras kepada pegawai negeri sipil diberikan sebanyak $10 \mathrm{~kg} /$ orang/bulan, atau setara itu yang diberikan dalam bentuk uang dengan besaran harga beras per-kg-nya ditetapkan oleh menteri keuangan;

b) Besaran tunjangan beras kepada anggota keluarga pegawai negeri sipil diberikan sebanyak $10 \mathrm{~kg} /$ orang/bulan atau setara setara itu yang diberikan dalam bentuk uang dengan besaran harga beras per kg nya ditetapkan oleh menteri keuangan;

c) Banyaknya jumlah orang yang dapat diberikan tunjangan beras adalah pegawai yang bersangkutan ditambah jumlah anggota keluarga yang tercantum dalam daftar gaji.

6) Tunjangan Khusus PPh

Tunjangan khusus $\mathrm{PPh}$ adalah tunjangan khusus pajak yang diberikan oleh pemerintah dalam rangka membantu pegawai negeri yang dikenakan pajak penghasilan.

7) Tunjangan Khusus Irian Jaya/Papua

Tunjangan khusus Irian Jaya/Papua adalah tunjangan khusus yang diberikan kepada pegawai negeri/calon pegawai negeri yang bekerja di provonsi Papua dan Irian Jaya Barat yang besarnya sesuai dengan ketentuan yang berlaku. Tunjangan khusus Irian Jaya/Papua diberikan dengan latar belakang bahwa pegawai yang berkedudukan di suatu daerah yang angka indeks kemahalan daerah tertentu yang ditunjuk sebagai dasar (standart). Ketentuanketentuan yang terkait dengan tunjangan khusus Irian Jaya/Papua sebagai berikut:

a) Diberikan kepada pegawai yang secara nyata berada dan bekerja di provinsi Papua dan Irian Jaya Barat;

b) Tunjangan khusus Irian Jaya/Papua diberikan pada bulan berkenaan berada dan bekerja di provinsi papua dan Irian Jaya Barat yang dibuktikan dengan Surat Pernyataan Melaksanakan Tugas;

c) Tunjangan khusus Irian Jaya/Papua dihentikan pada bulan berikutnya sejak pegawai yang bersangkutan secara nyata tidak berada dan bekerja di provinsi papua dan Irian Jaya Barat.

8) Tunjangan Pengabdian Wilayah Terpencil Tunjangan pengabdian wilayah terpencil adalah tunjangan yang diberikan kepada pegawai negeri yang bekerja atau bertempat tinggal di wilayah terpencil berdasarkan ketentuan yang berlaku. Latar belakang pemberian tunjangan pengabdian wilayah terpencil adalah 
karena pegawai negeri yang ditempatkan di wilayah terpencil cenderung mengalami permasalahan berat jika dibandingkan dengan mereka yang ditugaskan di wilayah lainnya.

Wilayah terpencil adalah wilayah yang sulit dalam berbagai aspek, seperti tidak/belum tersedia pelayanan umum, harga kebutuhan pokok yang sangat mahal, tidak/belum tersedia sarana komunikasi yang memadai. Kondisi wilayah terpencil tentu membutuhkan tingkat pengabdian yang tulus dari seorang pegawai negeri untuk ditempatkan/ditugaskan di daerah tersebut. Untuk itu pemerintah wajib memperhatikan kepentingan pegawai negeri dimaksud dalam bentuk pemberian tunjangan pengabdian.

9) Tunjangan Umum

Tunjangan umum adalah tunjangan yang diberikan dalam rangka meningkatkan mutu, prestasi, pengabdian, dan semangat kerja bagi calon pegawai negeri sipil/pegawai negeri sipil yang tidak menerima tunjangan jabatan struktural atau tunjangan jabatan fungsional atau tunjangan yang dipersamakan dengan tunjangan jabatan dengan ketentuan:

a) Besaran tunjangan umum diatur dalam Peraturan Pemerintah No. 12 Tahun 2006;

b) Tambahan tunjangan umum diberikan jika calon pegawai negeri sipi dan pegawai negeri sipil menerima penghasilan (gaji pokok, tunjangan keluarga, tunjangan beras, dan tunjangan umum) kurang dari Rp. 1.000.000 (satu juta rupiah);

c) Pembayaran tunjangan umum dihentikan terhitung mulai bulan berikutnya sejak pegawai negeri yang bersangkutan menerima tunjangan jabatan struktural atau tunjangan fungsional.

10) Tunjangan Perbaikan Penghasilan

Dalam rangka meningkatkan mutu, prestasi kerja, serta mencapai daya guna dan hasil guna yang sebesar-besarnya pemerintah dapat memberikan Tunjangan Perbaikan Penghasilan (TPP) untuk periode waktu tertentu.TPP dapat berupa tambahan penghasilan sebesar presentase tertentu atas gaji pokok ditambah tunjangan keluarga, atau besaran nilai nominal tertentu yang ditambahkan pada gaji kotor.Ketentuan tentang tunjangan perbaikan penghasilan diatur dalam Peraturan Pemerintah.

\section{Keterkaitan Organisasi dengan Kompensasi}

Weisbord dalam Thoha (2000) memberikan model untuk mendiagnosa organisasi yang sering dikenal dengan enam kotak Weisbord yang terdiri dari tujuan, struktur, sistem penghargaan, mekanisme tata kerja, tata hubungan, dan kepemimpinan. Faktor-faktor atau variabel organisasi Model Weisbord tersebut memiliki pengaruh terhadap prestasi kerja organisasi. Kerangka konsep yang dapat dikemukakan sebagai berikut :

\section{a. Tujuan}

Tujuan merupakan persyaratan utama dalam kehidupan suatu organisasi. Organisasi adalah merupakan suatu wadah kegiatan kerjasama dalam mencapai tujuan tertentu, sehingga setiap organisasi selalu mempunyai tujuan yang hendak diraihnya. Pencapaian tujuan sering diasumsikan untuk dijadikan sebagai tolok ukur prestasi kerja atau efektifitas suatu organisasi.

\section{b. Struktur Organisasi}

Dalam rangka mewujudkan tujuan organisasi, pada organisasi yang besar, sudah barang tentu diperlukan pengorganisasian dengan melakukan pembagian habis seluruh pesan dan tugas di antara para anggota maupun unsur-unsur yang ada sesuai dengan kebutuhannya. Jadi dengan demikian jelaslah sudah bahwa struktur organisasi adalah merupakan bentuk pengorganisasian dalam rangka mencapai tujuan organisasi.

\section{c. Tata Hubungan}

Tata hubungan yang baik adalah yang mampu menciptakan kondisi yang menjamin kelancaran komunikasi dari berbagai unsur yang ada. Unsurunsur dimaksud adalah individu dengan individu, individu dengan kelompok, kelompok dengan kelompok, dan kelompok dengan organisasi secara keseluruhan.

Faktor tata hubungan ini menjadi sangat penting karena mempunyai potensi pengaruh yang sangat cukup signifikan terhadap efektifitas organisasi, oleh sebab itu dengan tata hubungan yang jelas maka komunikasi akan berjalan dengan baik, proses kerjasama dan koordinasi dapat berjalan dengan lancar serta prestasi kerja pegawai yang tinggi sehingga pada akhirnya tujuan organisasi dapat lebih mudah tercapai.

\section{d. Sistem Penghargaan}

Penghargaan (reward) adalah merupakan salah satu kebutuhan dari kebutuhan manusia. Hal ini diperlukan karena seseorang yang telah berusaha dan bekerja dengan baik ingin mendapatkan penghargaan dari orang lain, dari atasannya maupun dari sesama karyawan.

Moenir (1987) menyatakan bahwa penghargaan sering disamakan dengan insentif, karena 
mempunyai kesamaan sifat dan makna. Sifat keduanya tidak membedakan dalam pemberian, tidak dibatasi oleh waktu, sedangkan maknanya adalah sama-sama pemberian. Namun waktu dikaji secara mendalam sebenarnya berbeda, terutama dalam maksud pemberiannya.

Penghargaan sama dengan namanya, dimaksudkan untuk menghargai terhadap jasa atau prestasi kerja karena telah menepati standart kerja yang ditetapkan, tetapi insentif adalah usaha dan cara-cara untuk mendorong pegawai/buruh bekerja dengan baik, sehingga prestasi kerjanya melebihi standart kerja yang telah ditetapkan, disini justru mengharap agar orang tersebut dapat berprestasi atau berjasa lebih baik dari yang sudah dilakukan. Jadi penghargaan mengandung unsur masa lalu, sedangkan insentif mengandung unsur masa depan. Dengan demikian penghargaan berupa insentip sangat berpengaruh terhadap prestasi kerja.

\section{e. Kepemimpinan}

Terry (1993) mengungkapkan bahwa kepemimpinan adalah aktifitas untuk mempengaruhi orang-orang supaya diarahkan mencapai tujuan organisasi. Kepemimpinan itu muncul karena faktor kebersamaan antara sekelompok individu dalam bekerjasama, dan hubungan di dalamnya yang satu mengendalikan yang lain (pemimpin) dan yang lain berusaha mengikuti (bawahan)

Bila dikaitkan dengan model Weisbord bahwa unsur kepemimpinan memiliki potensi sentral yang terkait erat dengan kondisi lima kotak unsur dalam organisasi lainnya. Kepemimpinan ini merupakan tugas utama seorang manajer untuk menciptakan suasana saling kerjasama yang sekaligus upaya untuk mempengaruhi orang lain atau kelompok kerja agar terus dan atau tetap memberikan dukungan, kesetiaan serta prestasi kerja pegawai yang tinggi bagi keberhasilan suatu organisasi.

\section{f. Mekanisme Tata Kerja}

Mekanisme tata kerja adalah merupakan sistem atau tatanan yang mengatur rangkaian berbagai proses kerja dalam mencapai tujuan dan atau bagaimana kegiatan manajemen atau pengelolaan organisasi itu dilakukan, bagaimana sistem perencanaan, sistem pengadaan dan pelaksanaan, serta sistem pengendaliannya, juga bagaimana keterkaitan antara satu dengan lainnya.

\section{METODE PENELITIAN}

Dalam menjelaskan permasalahan, digunakan pendekatan yuridis normatif. Penelitian yuridis normatif adalah penelitian yang mengacu kepada norma-norma hukum yang terdapat dalam perun- dang-undangan, peraturan-peraturan, dan kebijakan-kebijakan pemerintah. Dalam penelitian hukum normatif ini, yang diteliti adalah bahan pustaka atau data sekunder yang mencakup bahan hukum primer dan bahan hukum sekunder. Data primer diperoleh melalui wawancara mendalam (indepth interview) terhadap narasumber, sedangkan data sekunder diperoleh dari studi kepustakaan.

Tahapan penelitian ini meliputi :

\section{a. Tahapan pengumpulan data}

Tahapan ini penulis melakukan rangkaian kegiatan studi dokumen dengan cara membaca, mencatat, mengutip buku-buku atau referensi dan menelaah perundang-undangan, dokumen dan informasi lain yang ada hubungannya dengan restrukturisasi organisasi, kompensasi, alih jabatan struktural ke fungsional, struktur gaji, dan tunjangan Pegawai Negeri Sipil. Selanjutnya dilaksanakan studi lapangan yang merupakan sebuah usaha untuk mendapatkan data primer yang dilakukan dengan metode wawancara dengan responden. Wawancara mendalam telah dilakukan terhadap pihak-pihak terkait yang mengetahui proses alih jabatan dari jabatan struktural ke jabatan fungsional di PPDMA, yaitu Kepala Sub Bagian Kepegawaian dan Umum, Staf Sub Bagian Kepegawaian dan Umum, Petugas Pengelolaan Administrasi Belanja Pegawai (PPABP), dan Analis Kepegawaian yang menangani organisasi dan tata laksana.

\section{b. Pengolahan Data}

Dalam pengolahan data, penulis melakukan kegiatan seleksi data, klasifikasi data, dan sistematisasi data. Kegiatan seleksi data yaitu memilih data yang sesuai dengan obyek yang akan dibahas, klasifikasi data yaitu mengelompokkan data menjadi pokok bahasan sehingga sesuai dengan tujuan agar mudah menganalisis data yang akan ditentukan, sistematisasi data yaitu data yang telah diklasifikasi ditempatkan sesuai dengan posisi pokok permasalahan secara sistematis.

\section{c. Analisa Data}

Data yang diperoleh, dianalisa secara metode kualitatif, yaitu memaparkan kenyataankenyataan yang didasarkan pada hasil penelitian. Dari analisis data tersebut, dilanjutkan dengan menarik kesimpulan secara deduktif, yaitu cara berpikir yang didasarkan pada fakta-fakta yang bersifat umum untuk kemudian ditarik suatu kesimpulan yang khusus.

\section{PEMBAHASAN}

Perlunya transformasi organisasi pemerintahan sudah dinyatakan di dalam Rencana Pem- 
bangunan Jangka Panjang 2005-2025: "Pembangunan Jangka Panjang Nasional Tahun 2005-2015 merupakan kelanjutan dari pembangunan sebelumnya untuk mencapai tujuan pembangunan sebagaimana diamanatkan dalam Pembukaan Undang-Undang Dasar Negara Republik Indonesia Tahun 1945. Untuk itu, dalam 20 tahun ke depan (kini tinggal 10 tahun), sangat penting dan mendesak bagi bangsa Indonesia untuk melakukan penataan kembali berbagai langkah-langkah, antara lain di bidang pengelolaan sumber daya alam, sumber daya manusia, lingkungan hidup dan kelembagaannya sehingga bangsa Indonesia dapat mengejar ketertinggalannya dan mempunyai posisi sejajar serta daya saing yang kuat di dalam pergaulan masyarakat International."Pada saat ini kondisi birokrasi di Indonesia belum mengalami perubahan mendasar yang besar. Masih banyak permasalahan yang belum terselesaikan. Angka-angka statistik dan hasil survei menunjukkan masih rendahnya daya saing kita, masih rendahnya indeks persepsi korupsi, masih tinggi tingkat kemiskinan dan ketimpangan. Permasalahan itu makin meningkat kompleksitasnya dengan desentralisasi, demokratisasi, globalisasi, dan revolusi teknologi informasi.

Presiden Joko Widodo memberikan mandat bahwa "Sangat penting bagi kita untuk mereformasi birokrasi kita. Reformasi Struktural ! Agar lembaga semakin sederhana, semakin simpel, semakin lincah". Berdasarkan mandat tersebut, terbitlah Peraturan Presiden Nomor 68 Tahun 2019 tentang Organisasi Kementerian Negara sebagai Pedoman untuk Struktur Organisasi Kementerian. Langkah yang diambil yaitu Penyederhanaan eselonisasi menjadi 2 (dua) level, dan diganti dengan jabatan fungsional yang menghargai keahlian dan kompetensi, hal ini merupakan langkah penataan struktural yang mengalihkan Jabatan Struktural Eselon III ke bawah ke dalam Jabatan Fungsional.

Langkah penataan ini bertujuan untuk mendapatkan birokrasi yang adaptif, agile, produktif, inovatif dan kompetitif. Dalam rangka penataan struktural, diterbitkan Peraturan Pemerintah Nomor 17 tahun 2020 tentang Perubahan atas Peraturan Pemerintah Nomor 11 Tahun 2017 tentang Manajemen PNS, Peraturan Menteri PAN RB nomor 28 tahun 2019 tentang Penyetaraan jabatan Administrasi ke dalam Jabatan Fungsional, dan SE Menteri PANRB Nomor 384 Tahun 2019 tentang Langkah Strategis dan konkret Penyederhanaan Birokrasi.

Pusat Pengembangan Sumber Daya Manusia Aparatur (PPSDMA) memiliki 1 (satu) orang
Pejabat Eselon II, 4 (empat) orang Pejabat Eselon III dan 8 (delapan) orang Pejabat Eselon IV. Berkenaan dengan pengurangan jabatan eselon III dan IV dalam lingkup PPSDMA, PPSDMA harus memulai menyederhanakan struktur dengan mengalihkan pejabat Eselon III dan IV menjadi jabatan fungsional.

Jabatan-jabatan fungsional yang ada di lingkungan Kementerian Energi dan Sumber Daya Mineral yaitu : Analis Kebijakan, Perencana, Analis Anggaran, Analis Kepegawaian, Pranata Komputer, Analis Pengelolaan Keuangan APBN, Perancang Peraturan Perundang-undangan, Arsiparis, Pengelola Pengadaan Barang dan Jasa, Pranata Humas, Pustakawan, Statistisi, Pranata Laboratorium Pendidikan, Peneliti, Perekayasa, Instruktur, Inspektur Ketenagalistrikan, Inspektur Migas, Inspektur Tambang, Penyelidik Bumi, Pengamat Gunung Api, dan Widyaiswara. Untuk di lingkungan PPSDMA, jabatan fungsional yang sesuai dengan tugas dan fungsi organisasi dan diperbolehkan untuk diisi adalah Analis Kebijakan, Perencana, Analis Anggaran, Analis Kepegawaian, Pranata Komputer, Analis Pengelolaan Keuangan APBN, Arsiparis, Pengelola Pengadaan Barang dan Jasa, Pranata Humas, Pustakawan, dan Widyaiswara.

Pada Jabatan Struktural Eselon III, memiliki beban pekerjaan harus menyelesaikan tugas yang diberikan oleh atasannya yaitu Eselon II, dan beberapa tugas tambahan yang diminta oleh Pejabat Eselon I apabila tugas itu terkait dalam perencanaan program organisasi, disamping itu juga bertanggungjawab atas pemeriksaan dan persetujuan seluruh pekerjaan yang diselesaikan oleh Pejabat Eselon IV. Sementara itu, Pejabat Eselon IV, bertanggungjawab untuk menyelesaikan tugas yang diberikan oleh atasannya yaitu Pejabat Eselon III dan juga bertanggungjawab untuk memeriksa hasil pekerjaan dari jabatan pelaksana yang menjadi bawahannya.

Untuk Jabatan Fungsional tertentu, tanggung jawab pekerjaannya hanya untuk menjalankan tugas fungsinya sebagai jabatan fungsional. Jabatan Fungsional bertanggungjawab kepada pimpinan oganisasi dalam hal ini Pejabat Eselon II. Pelaksanaan tugasnya bersifat mandiri dan kegiatannya dapat diukur dengan satuan nilai atau akumulasi nilai butir-butir kegiatan dalam bentuk angka kredit. Meskipun demikian, jabatan fungsional karena bekerja secara mandiri, lebih banyak bekerja diluar waktu jam kerja, hal ini disebabkan karena perlunya persiapan dalam menjalankan tugas mandirinya tersebut. Jabatan fungsional juga mengerjakan tugas-tugas tam- 
bahan untuk mendukung proses bisnis dari organisasi, sehingga waktunya lebih banyak mengerjakan tugas-tugas tambahannya dibanding mengerjakan tugas fungsinya secara mandiri. Hal ini menunjukan bahwa belum seimbangnya bobot pekerjaan jabatan fungsional dengan kompensasi yang didapat.

Untuk Jabatan Fungsional Analis Anggaran, dan Analis Pengelolaan Keuangan APBN belum diatur mengenai besaran tunjangan, sementara itu tunjangan Jabatan Struktural dan Jabatan Fungsional Analis Kebijakan, Perencana, Analis Kepegawaian, Pranata Komputer, Arsiparis, Pengelola Pengadaan Barang dan Jasa, Pranata Humas, Pustakawan, dan Widyaiswara diatur berdasarkan Peraturan Presiden sebagai berikut:

Tabel 1.Tunjangan Jabatan Struktural menurut Peraturan Presiden Nomor 26 Tahun 2007

\begin{tabular}{|c|c|c|}
\hline No. & Eselon & Besarnya Tunjangan \\
\hline 1 & I A & Rp. 5.500 .000 \\
\hline 2 & I B & Rp. 4.375 .000 \\
\hline 3 & II A & Rp. 3.250 .000 \\
\hline 4 & II B & Rp. 2.025 .000 \\
\hline 5 & III A & Rp. 1.260 .000 \\
\hline 6 & III B & Rp. 980.000 \\
\hline 7 & IV A & Rp. 540.000 \\
\hline 8 & IV B & Rp. 490.000 \\
\hline 9 & V A & Rp. 360.000 \\
\hline
\end{tabular}

Dibawah ini ditampilkan tabel tunjangan Jabatan Fungsional yang relevan dengan tugas dan fungsi PPSDMA, kelas jabatan berdasarkan Keputusan Menteri Energi dan Sumber Daya Mineral, dan besaran tunjangan kinerja yang berlaku di Kementerian Energi dan Sumber Daya Mineral berdasarkan Peraturan Presiden, antara lain:

Tabel 2. Tunjangan Jabatan Fungsional Analis Kepegawaian menurut Peraturan Presiden Nomor 17 Tahun 2013

\begin{tabular}{|c|c|c|}
\hline $\begin{array}{c}\text { Jabatan } \\
\text { Fungsional }\end{array}$ & $\begin{array}{c}\text { Jenjang } \\
\text { Jabatan }\end{array}$ & $\begin{array}{c}\text { Besarnya } \\
\text { Tunjangan }\end{array}$ \\
\hline \multirow{4}{*}{$\begin{array}{c}\text { Analis } \\
\text { Kepegawaian }\end{array}$} & Madya & Rp. 1.080 .000 \\
\cline { 2 - 3 } & Muda & Rp. 840.000 \\
\cline { 2 - 3 } & Pertama & Rp. 480.000 \\
\cline { 2 - 3 } & Penyelia & Rp. 600.000 \\
\cline { 2 - 3 } & $\begin{array}{c}\text { Pelaksana } \\
\text { Lanjutan }\end{array}$ & Rp. 420.000 \\
\cline { 2 - 3 } & Pelaksana & Rp. 330.000 \\
\hline
\end{tabular}

Tabel 3. Tunjangan Jabatan Fungsional Widyaiswara menurut Peraturan Presiden Nomor 59 Tahun 2007

\begin{tabular}{|c|c|c|}
\hline $\begin{array}{c}\text { Jabatan } \\
\text { Fungsional }\end{array}$ & $\begin{array}{c}\text { Jenjang } \\
\text { Jabatan }\end{array}$ & $\begin{array}{c}\text { Besarnya } \\
\text { Tunjangan }\end{array}$ \\
\hline \multirow{4}{*}{ Widyaiswara } & Utama & Rp. 1.400 .000 \\
\cline { 2 - 3 } & Madya & Rp. 1.000 .000 \\
\cline { 2 - 3 } & Muda & Rp. 700.000 \\
\cline { 2 - 3 } & Pertama & Rp. 325.000 \\
\hline
\end{tabular}

Tabel 4.Tunjangan Jabatan Fungsional

Perencana menurut Peraturan Presiden Nomor 44 Tahun 2007

\begin{tabular}{|c|c|c|}
\hline $\begin{array}{c}\text { Jabatan } \\
\text { Fungsional }\end{array}$ & $\begin{array}{c}\text { Jenjang } \\
\text { Jabatan }\end{array}$ & $\begin{array}{c}\text { Besarnya } \\
\text { Tunjangan }\end{array}$ \\
\hline \multirow{3}{*}{ Perencana } & Utama & Rp. 1.400 .000 \\
\cline { 2 - 3 } & Madya & Rp. 1.200 .000 \\
\cline { 2 - 3 } & Muda & Rp. 750.000 \\
\cline { 2 - 3 } & Pertama & Rp. 325.000 \\
\hline
\end{tabular}

Tabel 5.Tunjangan Jabatan Fungsional Pustakawan menurut Peraturan Presiden Nomor 71 Tahun 2013

\begin{tabular}{|c|c|c|}
\hline $\begin{array}{c}\text { Jabatan } \\
\text { Fungsional }\end{array}$ & $\begin{array}{c}\text { Jenjang } \\
\text { Jabatan }\end{array}$ & $\begin{array}{c}\text { Besarnya } \\
\text { Tunjangan }\end{array}$ \\
\hline \multirow{4}{*}{ Pustakawan } & Utama & Rp. 1.300 .000 \\
\cline { 2 - 3 } & Madya & Rp. 1.100 .000 \\
\cline { 2 - 3 } & Muda & Rp. 800.000 \\
\cline { 2 - 3 } & Pertama & Rp. 520.000 \\
\hline
\end{tabular}

Tabel 6.Tunjangan Jabatan Fungsional Pranata Humas menurut Peraturan Presiden Nomor 29 Tahun 2007

\begin{tabular}{|c|c|c|}
\hline $\begin{array}{c}\text { Jabatan } \\
\text { Fungsional }\end{array}$ & $\begin{array}{c}\text { Jenjang } \\
\text { Jabatan }\end{array}$ & $\begin{array}{c}\text { Besarnya } \\
\text { Tunjangan }\end{array}$ \\
\hline \multirow{2}{*}{$\begin{array}{c}\text { Pranata } \\
\text { Humas }\end{array}$} & Madya & Rp. 650.000 \\
\cline { 2 - 3 } & Muda & Rp. 400.000 \\
\cline { 2 - 3 } & Pertama & Rp. 270.000 \\
\hline
\end{tabular}

Tabel 7. Tunjangan Jabatan Fungsional Arsiparis menurut Peraturan Presiden Nomor 15 Tahun 2017

\begin{tabular}{|c|c|c|}
\hline $\begin{array}{c}\text { Jabatan } \\
\text { Fungsional }\end{array}$ & $\begin{array}{c}\text { Jenjang } \\
\text { Jabatan }\end{array}$ & $\begin{array}{c}\text { Besarnya } \\
\text { Tunjangan }\end{array}$ \\
\hline \multirow{4}{*}{ Arsiparis } & Utama & Rp. 1.300 .000 \\
\cline { 2 - 3 } & Madya & Rp. 1.100 .000 \\
\cline { 2 - 3 } & Muda & Rp. 800.000 \\
\cline { 2 - 3 } & Pertama & Rp. 520.000 \\
\hline
\end{tabular}


Tabel 8. Tunjangan Jabatan Fungsional

Pengelola Pengadaan Barang dan Jasa menurut

Peraturan Presiden Nomor 109 Tahun 2016

\begin{tabular}{|c|c|c|}
\hline $\begin{array}{c}\text { Jabatan } \\
\text { Fungsional }\end{array}$ & $\begin{array}{c}\text { Jenjang } \\
\text { Jabatan }\end{array}$ & $\begin{array}{c}\text { Besarnya } \\
\text { Tunjangan }\end{array}$ \\
\hline $\begin{array}{c}\text { Pengelola } \\
\text { Pengadaan } \\
\begin{array}{c}\text { Barang dan } \\
\text { Jasa }\end{array}\end{array}$ & Madya & Rp. 1.150 .000 \\
\cline { 2 - 3 } & Muda & Rp. 876.000 \\
\cline { 2 - 3 } & Pertama & Rp. 493.000 \\
\hline
\end{tabular}

Tabel 9. Tunjangan Jabatan Fungsional Analis Kebijakan menurut Peraturan Presiden Nomor 68 Tahun 2017

\begin{tabular}{|c|c|c|}
\hline $\begin{array}{c}\text { Jabatan } \\
\text { Fungsional }\end{array}$ & $\begin{array}{c}\text { Jenjang } \\
\text { Jabatan }\end{array}$ & $\begin{array}{c}\text { Besarnya } \\
\text { Tunjangan }\end{array}$ \\
\hline \multirow{4}{*}{$\begin{array}{c}\text { Analis } \\
\text { Kebijakan }\end{array}$} & Utama & Rp. 1.685 .000 \\
\cline { 2 - 3 } & Madya & Rp. 1.150 .000 \\
\cline { 2 - 3 } & Muda & Rp. 920.000 \\
\cline { 2 - 3 } & Pertama & Rp. 540.000 \\
\hline
\end{tabular}

Tabel 10. Tunjangan Jabatan Fungsional Pranata Komputer menurut Peraturan Presiden Nomor 9 Tahun 2017

\begin{tabular}{|c|c|c|}
\hline $\begin{array}{c}\text { Jabatan } \\
\text { Fungsional }\end{array}$ & $\begin{array}{c}\text { Jenjang } \\
\text { Jabatan }\end{array}$ & $\begin{array}{c}\text { Besarnya } \\
\text { Tunjangan }\end{array}$ \\
\hline \multirow{3}{*}{$\begin{array}{c}\text { Pranata } \\
\text { Komputer }\end{array}$} & Utama & Rp. 1.500 .000 \\
\cline { 2 - 3 } & Madya & Rp. 1.260 .000 \\
\cline { 2 - 3 } & Muda & Rp. 960.000 \\
\cline { 2 - 3 } & Pertama & Rp. 540.000 \\
\hline
\end{tabular}

Tabel 11. Kelas Jabatan di lingkungan Kementerian Energi dan Sumber Daya Mineral menurut Keputusan Menteri Energi dan Sumber

Daya Mineral Nomor 177 K/70/MEM/2019

\begin{tabular}{|c|c|c|}
\hline No. & Jabatan & $\begin{array}{c}\text { Kelas } \\
\text { Jabatan }\end{array}$ \\
\hline A. & Jabatan Administrator & \multirow{2}{*}{13} \\
\hline & Kepala Balai & \multirow{2}{*}{13} \\
\hline & Kepala Museum & \multirow{2}{*}{ Kepala Bagian } \\
\hline & $\begin{array}{c}\text { Kepala Sub Direktorat } \\
\text { Kepala Bidang }\end{array}$ & \multirow{2}{*}{ Babatan Pengawas } \\
\hline & Kepala Sub Bagian & \multirow{2}{*}{9} \\
\hline & $\begin{array}{c}\text { Kepala Seksi } \\
\text { Kepala Sub Bidang }\end{array}$ & \multirow{2}{*}{8} \\
\hline & $\begin{array}{c}\text { Kepala Sub Bagian Tata } \\
\text { Usaha Inspektorat }\end{array}$ & \\
\hline
\end{tabular}

Tabel 12. Tunjangan Kinerja Pegawai di lingkungan Kementerian Energi dan Sumber Daya Mineral menurut Peraturan Presiden Nomor 94 Tahun 2018

\begin{tabular}{|c|c|c|}
\hline No. & $\begin{array}{c}\text { Kelas } \\
\text { Jabatan }\end{array}$ & $\begin{array}{c}\text { Tunjangan Kinerja } \\
\text { Per Kelas Jabatan }\end{array}$ \\
\hline 1 & 17 & Rp. 33.240 .000 \\
\hline 2 & 16 & Rp. 27.577 .500 \\
\hline 3 & 15 & Rp. 19.280 .000 \\
\hline 4 & 14 & Rp. 17.064 .000 \\
\hline 5 & 13 & Rp. 10.936 .000 \\
\hline 6 & 12 & Rp. 9.896 .000 \\
\hline 7 & 11 & Rp. 8.757 .600 \\
\hline 8 & 10 & Rp. 5.979 .200 \\
\hline 9 & 9 & Rp. 5.079 .200 \\
\hline 10 & 8 & Rp. 4.595 .150 \\
\hline 11 & 7 & Rp. 3.915 .950 \\
\hline 12 & 6 & Rp. 3.510 .400 \\
\hline 13 & 5 & Rp. 3.134 .250 \\
\hline 14 & 4 & Rp. 2.985 .000 \\
\hline 15 & 3 & Rp. 2.898 .000 \\
\hline 16 & 2 & Rp. 2.708 .250 \\
\hline 17 & 1 & Rp. 2.531 .250 \\
\hline
\end{tabular}

Berdasarkan uraian diatas, maka dapat digambarkan simpulan perbandingan besaran tunjangan jabatan dan tunjangan kinerja antara jabatan struktural eselon III dan eselon IV dengan jabatan fungsional tertentu pada level/tingkatan setara yakni :

Tabel 13. Tabel Perbandingan Besaran Tunjangan Jabatan dan Tunjangan Kinerja

\begin{tabular}{|l|l|l|l|l|}
\hline No & Struktural & $\begin{array}{l}\text { Analis } \\
\text { Kepegawaian }\end{array}$ & Widyaiswara & Perencana \\
\hline 1 & Eselon III & Madya & Madya & Madya \\
\hline & Tunjangan & Tunjangan & Tunjangan & Tunjangan \\
& Jabatan & Jabatan & Jabatan & Jabatan \\
& 1.260 .000 & 1.080 .000 & 1.000 .000 & 1.200 .000 \\
\hline & Tunjangan & Tunjangan & Tunjangan & Tunjangan \\
& Kinerja & Kinerja & Kinerja & Kinerja \\
& Level 12) & (Level 11) & (Level 11) & (Level 11) \\
& 9.896 .000 & 8.757 .600 & 8.757 .600 & 8.757 .600 \\
\hline & Jumlah & Jumlah & Jumlah & Jumlah \\
& Total & Total & Total & Total \\
& $\mathbf{1 1 . 1 5 6 . 0 0 0}$ & $\mathbf{9 . 8 3 7 . 6 0 0}$ & $\mathbf{9 . 7 5 7 . 6 0 0}$ & $\mathbf{9 . 9 5 7 . 6 0 0}$ \\
\hline 2 & Eselon IV & Muda & Muda & Muda \\
\hline & Tunjangan & Tunjangan & Tunjangan & Tunjangan \\
& Jabatan & Jabatan & Jabatan & Jabatan \\
& 540.000 & 840.000 & 700.000 & 750.000 \\
\hline & Tunjangan & Tunjangan & Tunjangan & Tunjangan \\
& Kinerja & Kinerja & Kinerja & Kinerja \\
& (Level 9) & Level 9) & (Level 9) \\
& Level 9) & Level & 5.079.200 \\
\hline & 5.079 .200 & 5.079 .200 & 5.079 .200 & Jumlah \\
& Jumlah & Jumlah Total & Jumlah Total & Jumlah \\
& Total & $\mathbf{5 . 9 1 9 . 2 0 0}$ & $\mathbf{5 . 7 7 9 . 2 0 0}$ & Total \\
& $\mathbf{5 . 6 1 9 . 2 0 0}$ & & & $\mathbf{5 . 8 2 9 . 2 0 0}$ \\
\hline
\end{tabular}




\begin{tabular}{|c|c|c|c|c|}
\hline No & Struktural & $\begin{array}{l}\text { Pranata } \\
\text { Komputer }\end{array}$ & $\begin{array}{l}\text { Analis } \\
\text { Kebijakan }\end{array}$ & $\begin{array}{l}\text { Pengelola } \\
\text { Pengadaan } \\
\text { Barang dan } \\
\text { Jasa }\end{array}$ \\
\hline \multirow[t]{4}{*}{1} & Eselon III & Madya & Madya & Madya \\
\hline & $\begin{array}{l}\text { Tunjangan } \\
\text { Jabatan } \\
1.260 .000\end{array}$ & $\begin{array}{l}\text { Tunjangan } \\
\text { Jabatan } \\
1.260 .000\end{array}$ & $\begin{array}{l}\text { Tunjangan } \\
\text { Jabatan } \\
1.150 .000\end{array}$ & $\begin{array}{l}\text { Tunjangan } \\
\text { Jabatan } \\
1.150 .000\end{array}$ \\
\hline & $\begin{array}{l}\text { Tunjangan } \\
\text { Kinerja } \\
\text { (Level 12) } \\
9.896 .000\end{array}$ & $\begin{array}{l}\text { Tunjangan } \\
\text { Kinerja } \\
\text { (Level 11) } \\
8.757 .600\end{array}$ & $\begin{array}{l}\text { Tunjangan } \\
\text { Kinerja } \\
\text { (Level 11) } \\
8.757 .600\end{array}$ & $\begin{array}{l}\text { Tunjangan } \\
\text { Kinerja } \\
\text { (Level 11) } \\
8.757 .600\end{array}$ \\
\hline & $\begin{array}{l}\text { Jumlah } \\
\text { Total } \\
\text { 11.156.000 }\end{array}$ & $\begin{array}{l}\text { Jumlah } \\
\text { Total } \\
\text { 10.017.600 }\end{array}$ & $\begin{array}{l}\text { Jumlah } \\
\text { Total } \\
9.907 .600\end{array}$ & $\begin{array}{l}\text { Jumlah } \\
\text { Total } \\
9.907 .600\end{array}$ \\
\hline \multirow[t]{4}{*}{2} & Eselon IV & Muda & Muda & Muda \\
\hline & $\begin{array}{l}\text { Tunjangan } \\
\text { Jabatan } \\
540.000\end{array}$ & $\begin{array}{l}\text { Tunjangan } \\
\text { Jabatan } \\
960.000\end{array}$ & $\begin{array}{l}\text { Tunjangan } \\
\text { Jabatan } \\
920.000\end{array}$ & $\begin{array}{l}\text { Tunjangan } \\
\text { Jabatan } \\
876.000\end{array}$ \\
\hline & $\begin{array}{l}\text { Tunjangan } \\
\text { Kinerja } \\
\text { (Level 9) } \\
5.079 .200\end{array}$ & $\begin{array}{l}\text { Tunjangan } \\
\text { Kinerja } \\
\text { (Level 9) } \\
5.079 .200\end{array}$ & $\begin{array}{l}\text { Tunjangan } \\
\text { Kinerja } \\
\text { (Level 9) } \\
5.079 .200\end{array}$ & $\begin{array}{l}\text { Tunjangan } \\
\text { Kinerja } \\
\text { (Level 9) } \\
5.079 .200\end{array}$ \\
\hline & $\begin{array}{l}\text { Jumlah } \\
\text { Total } \\
5.619 .200 \\
\end{array}$ & $\begin{array}{l}\text { Jumlah } \\
\text { Total } \\
\text { 6.039.200 } \\
\end{array}$ & $\begin{array}{l}\text { Jumlah } \\
\text { Total } \\
5.999 .200 \\
\end{array}$ & $\begin{array}{l}\text { Jumlah } \\
\text { Total } \\
\text { 5.955.200 } \\
\end{array}$ \\
\hline \multicolumn{2}{|c|}{ No. } & Struktural & Arsiparis & Pustakawan \\
\hline \multirow[t]{4}{*}{1} & & Eselon III & Madya & Madya \\
\hline & & $\begin{array}{l}\text { Tunjangan } \\
\text { Jabatan } \\
1.260 .000\end{array}$ & $\begin{array}{l}\text { Tunjangan } \\
\text { Jabatan } \\
1.100 .000\end{array}$ & $\begin{array}{l}\text { Tunjangan } \\
\text { Jabatan } \\
1.100 .000\end{array}$ \\
\hline & & $\begin{array}{l}\text { Tunjangan } \\
\text { Kinerja } \\
\text { (Level 12) } \\
9.896 .000\end{array}$ & $\begin{array}{l}\text { Tunjangan } \\
\text { Kinerja } \\
\text { (Level 11) } \\
8.757 .600\end{array}$ & $\begin{array}{l}\text { Tunjangan } \\
\text { Kinerja } \\
\text { (Level 11) } \\
8.757 .600\end{array}$ \\
\hline & & $\begin{array}{l}\text { Jumlah } \\
\text { Total } \\
\mathbf{1 1 . 1 5 6 . 0 0 0}\end{array}$ & $\begin{array}{l}\text { Jumlah } \\
\text { Total } \\
9.857 .600\end{array}$ & $\begin{array}{l}\text { Jumlah } \\
\text { Total } \\
\mathbf{9 . 8 5 7 . 6 0 0}\end{array}$ \\
\hline \multirow[t]{4}{*}{2} & & Eselon IV & Muda & Muda \\
\hline & & $\begin{array}{l}\text { Tunjangan } \\
\text { Jabatan } \\
540.000 \\
\end{array}$ & $\begin{array}{l}\text { Tunjangan } \\
\text { Jabatan } \\
800.000\end{array}$ & $\begin{array}{l}\text { Tunjangan } \\
\text { Jabatan } \\
800.000\end{array}$ \\
\hline & & $\begin{array}{l}\text { Tunjangan } \\
\text { Kinerja } \\
\text { (Level 9) } \\
5.079 .200\end{array}$ & $\begin{array}{l}\text { Tunjangan } \\
\text { Kinerja } \\
\text { (Level 9) } \\
5.079 .200\end{array}$ & $\begin{array}{l}\text { Tunjangan } \\
\text { Kinerja } \\
\text { (Level 9) } \\
5.079 .200\end{array}$ \\
\hline & & $\begin{array}{l}\text { Jumlah } \\
\text { Total } \\
5.619 .200\end{array}$ & $\begin{array}{l}\text { Jumlah } \\
\text { Total } \\
\text { 5.879.200 }\end{array}$ & $\begin{array}{l}\text { Jumlah } \\
\text { Total } \\
\mathbf{5 . 8 7 9 . 2 0 0}\end{array}$ \\
\hline
\end{tabular}

Sumber : Hasil olah data 2020

Penghasilan pegawai juga dapat dikaitkan dengan tingkatan jabatan masing-masing pegawai. Tingkatan jabatan dapat mempengaruhi besar kecilnya tunjangan kinerja yang diberikan kepada setiap pegawai. Tingkatan jabatan diukur berdasarkan kelas jabatan dan nilai jabatan. Semakin besar kelas jabatan dan nilai jabatan seorang pegawai, maka semakin besar pula nominal tunjangan kinerja yang diterimanya.

Berdasarkan tingkatan jabatan, untuk jabatan struktural eselon III berada pada kelas jabatan 12 sampai dengan 13, sedangkan untuk jabatan struktural eselon IV berada pada kelas jabatan 8 sampai dengan 9, disisi lain, untuk jabatan fungsional Pranata Komputer, Perencana, Widyaiswara, Analis Kepegawaian, Analis Kebijakan, Pengelola Pengadaan Barang dan Jasa, Arsiparis, dan Pustakawan yang selevel dengan jabatan eselon III berdasarkan Keputusan Menteri Energi dan Sumber Daya Mineral Nomor 177 K/70/MEM/2019 berada pada kelas jabatan 11 dan untuk jabatan fungsional Pranata Komputer, Perencana, Widyaiswara, Analis Kepegawaian, Analis Kebijakan, Pengelola Pengadaan Barang dan Jasa, Arsiparis, dan Pustakawan yang selevel dengan jabatan eselon IV berada pada kelas jabatan 9 .

Berdasarkan perbandingan pada tabel 13, bisa dianalisa bahwa tunjangan jabatan yang diterima oleh pejabat struktural eselon III tidak jauh berbeda dengan fungsional Pranata Komputer sementara dengan fungsional Perencana, Widyaiswara, Analis Kepegawaian, Analis Kebijakan, Pengelola Pengadaan Barang dan Jasa, Arsiparis, dan Pustakawan cukup jauh perbedaannya.

Sementara itu, tunjangan yang diterima oleh pejabat eselon IV cukup jauh berbeda dan lebih kecil dibandingkan dengan tunjangan yang diterima oleh fungsional Pranata Komputer, Perencana, Widyaiswara, Analis Kepegawaian, Analis Kebijakan, Pengelola Pengadaan Barang dan Jasa, Arsiparis, dan Pustakawan. Penghasilan pejabat eselon IV akan mengalami peningkatan walaupun tidak terlalu signifikan, tetapi mengalami kenaikan.

Dalam penataan organisasi ini, Jabatan Struktural yang beralih ke Jabatan Fungsional Tertentu, tentunya harus menyesuaikan dengan kebutuhan organisasi dan sesuai dengan tugas dan fungsi dari PPSDMA meskipun dalam penghasilan tidak sama, dimana penghasilan sebagai pejabat eselon III lebih besar dibandingkan dengan pejabat fungsional tertentu yang setara dan pejabat eselon IV mengalami kenaikan penghasilan apabila beralih ke jabatan fungsional tertentu yang setara.

\section{PENUTUP \\ Kesimpulan}

Transformasi organisasi pemerintah harus ditandai dengan pengembangan kepemimpinan transformasi dengan visioner yang terukur pada berbagai level kepemimpinan dalam organisasi pemerintah, hal ini sangat diperlukan guna memastikan setiap inovasi yang dikembangkan dapat memberikan nilai tambah kualitas pelayanan, menyelaraskan visi dan lingkungan internal yang diimbangi dengan kemampuan merespons perubahan lingkungan eksternal yang bergerak cepat dalam era Revolusi Industri 4.0 ini.

Dalam penataan organisasi PPSDMA, Jabatan Struktural yang beralih ke Jabatan Fungsional 
Tertentu, tentunya harus menyesuaikan dengan kebutuhan organisasi dan sesuai dengan tugas dan fungsi dari PPSDMA. Penghasilan atau tunjangan yang diterima pegawai menyiratkan bahwa besarnya tunjangan yang akan diterima pegawai dalam jabatan struktural tunjangan jabatan yang diterima oleh pejabat struktural eselon III tidak jauh berbeda dengan fungsional Pranata Komputer sementara dengan fungsional Perencana, Widyaiswara, Analis Kepegawaian, Analis Kebijakan, Pengelola Pengadaan Barang dan Jasa, Arsiparis, dan Pustakawan cukup jauh perbedaannya, sementara itu berbeda yang dialami oleh pegawai dalam jabatan struktural eselon IV akan menerima kenaikan jumlah tunjangan dibandingkan dengan ketika masih duduk di jabatan struktural eselon IV ketika beralih menjadi pejabat fungsional tertentu yang setara.

\section{Saran}

1. Perlu kematangan perencanaan terhadap kebutuhan jabatan fungsional sehingga beban tugas organisasi bisa sesuai dengan jumlah pegawai.

2. Perencanaan pengembangan jabatan fungsional sangat diperlukan sebagai pengembangan kompetensi fungsional yang merupakan ujung tombak dari PPSDMA.

3. Pada jabatan fungsional tertentu, besaran tunjangan belum didasarkan pada perhitungan bobot jabatan sehingga kurang proporsional dibandingkan dengan besaran tunjangan pada jabatan struktural yang setingkat.

4. Penyesuaian besaran tunjangan untuk jabatan fungsional tertentu yang belum sesuai dengan bobot jabatan atau dengan tunjangan jabatan fungsional tertentu lainnya, yang nantinya akan mendorong motivasi pegawai yang telah pindah ke jabatan fungsional tertentu.

\section{DAFTAR PUSTAKA}

\section{Buku}

Antony, W.P. and P.L. Parrewe, K.M. Kacmar (1996). Strategic Human Resource Management, The Dryden Press, Florida, USA.

Flippo, Edwin. (1990). Personnel Management. Jakarta: Airlangga

Gouillart dan Kelly (1995), Transforming the Organization, Mc Graw Hill, New York USA

Handoko, T. Hani. (1993). Manajemen Personalia dan Sumberdaya Manusia edisi 2.Yogyakarta: BPFE.

Handoko, T. Hani. (2012). Manajemen Personalia dan Sumber Daya Manusia. Yogyakarta. BPFE

Hasibuan, (2010), Manajemen Sumber Daya Manusia, Jakarta, Bumi Aksara
Henderson, R.I., (1994) 4. Compensation Management, Prentice Hal, New Jersey, USA.

Herman, Sofyandi. (2008). Manajemen Sumber Daya Manusia. Yogyakarta: Graha Ilmu

Kanungo, R.N. and M. Menconca, (1992). Compensation: Effective Reward Management, Butterworths, Canada.

Kismono, Gugup, 2011, Bisnis Pengantar, Edisi Dua, BPFE UGM, Yogyakarta

Lawler, E.E., (1971). Pay and Organizational Effectiveness: A Psychological View, McGrawHill, New York, USA.

Mangkunegara, Anwar Prabu, Manajemen Sumber daya Manusia, Bandung, PT. Remaja Rosdakarya.

Mangkuprawira, Sjafri. 2011. Manajemen Sumber Daya Manusia Strategik (edisi kedua). Ghalia Indonesia: Bogor

Milkovich, G.T. and J.M. Newman, (1996). Compensation, Richard D. Irwin, Chicago, USA.

Moenir, 1987, Pendekatan Manusiawi dan Organisasi terhadap pembinaan Kepegawaian, Jakarta Gunung Agung.

Notoatmodjo, Soekidjo. 2009. Pengembangan Sumber Daya Manusia, Jakarta, Rineka Cipta

Ranupandojo, Heidjrahman dan Suad Husnan. (1983). Manajemen Personalia edisi 2. Yogyakarta: BPFE

Rivai, Veithzal. 2009. Manajemen Sumber Daya Manusia Untuk Perusahaan Dari Teori ke Praktik. Jakarta: Raja Grafindo Persada

Simamora, Henry. (2004). Manajemen Sumber Daya Manusia, Yogyakarta: STIA YKPN

Sedarmayanti, (2000), Restrukturisasi dan Pemberdayaan Organisasi untuk Menghadapi Dinamika Perubahan Lingkungan, Bandung, Masdar Maju

Thoha, Miftah, 2000, Perilaku Organisasi, Konsep Dasar, dan Aplikasinya, Jakarta, PT. Raja Grafindo

Quaid, M. (1993). Job Evaluation: The Myth of Equitable Assesment, University of Toronto Press, New York.

Wasistiono, Sadu, 2002, Penyelenggaraan Pemeintah Daerah, Bandung, Fokusmedia

Wether, W.B. Jr and K. Davis, (1996). Human Resources and Personnel Management, Fifth Edition, McGraw-Hil, New York, USA.

\section{Jurnal}

Adams, J.S. (1965) Inequity in Social Exchange. Advances in Experimental Social ... Jeffrey R. Oliver, Lindon J. Robison

Conway, B.M., (June 1984). Salary Surveys: 
Avoid the Pitfalls, Personnel Journal, p. 26-65.

Hackman, J. R., \& Lawler, E. E. (1971). Employee reactions to job characteristics. Journal of Applied Psychology, 55(3), 259-286

Hoffman, C.C. and k.P. Hoffaman, (January 1987). Does Comparable Worth Obscure the Real Issues?, Personal Journal, p. 83-95.

Madigan, R.M. and D.H. Hoover, (March 1986). Effect of Alternative Job Evaluation Methods on Decisions Involving Pay Equity, Academy of Managemen Journal, p.84-100

Prasetyo, Hendrik Budhi (2009), Tesis, Perubahan Organisasi pada Pusdik Brimob, Studi Kasus Terhadap Pemberlakuan Keputusan Kapolri Nomor Pol Kep/53/X/2002, Universitas Indonesia

Smith, E.S., (February 1990). Support Objectives Using Base Compensation, Personal Journal, p. $86-90$

Terry, Michael, June 1993, Workplace Unions And Workplace Industrial Relation : The Italian Experience

The Economist, (July 1993). Low Paid, with Children,b p.26

\section{Peraturan}

Peraturan Pemerintah Nomor 21 Tahun 2004 tentang Penyusunan Rencana Kerja Anggaran Kementrian Negara/Lembaga

Peraturan Pemerintah No. 12 Tahun 2006 tentang Perubahan Ketujuh Atas Peraturan Pemerintah Nomor 145 Tahun 2000 Tentang Kelompok Barang Kena Pajak Yang Tergolong Mewah Yang Dikenakan Pajak Penjualan Atas Barang Mewah
Peraturan Pemerintah No. 26 Tahun 2007 tentang Tunjangan Jabatan Struktural

Peraturan Pemerintah No. 8 Tahun 2009 tentang Perubahan Kesebelas Atas Peraturan Pemerintah Nomor 7 Tahun 1977 Tentang Peraturan Gaji Pegawai Negeri Sipil

Peraturan Presiden Nomor 44 Tahun 2007 tentang Tunjangan jabatan Fungsional Perencana

Peraturan Presiden Nomor 59 Tahun 2007 tentang Tunjangan Jabatan Fungsional Widyaiswara

Peraturan Presiden Nomor 17 Tahun 2013 tentang Tunjangan Jabatan Fungsional Analis Kepegawaian

Peraturan Presiden Nomor 94 Tahun 2018 tentang Tunjangan Kinerja Pegawai di lingkungan Kementerian Energi dan Sumber Daya Mineral

Keputusan Menteri Energi dan Sumber Daya Mineral Nomor 177 K/70/MEM/2019 tentang Kelas Jabatan di lingkungan Kementerian Energi dan Sumber Daya Mineral

Perdirjen Perbendaharaan No PER-37/PB/2009 nggal Tentang: Petunjuk Teknis Pengalihan Pengelolaan Administrasi Belanja Pegawai Negeri Sipil 